
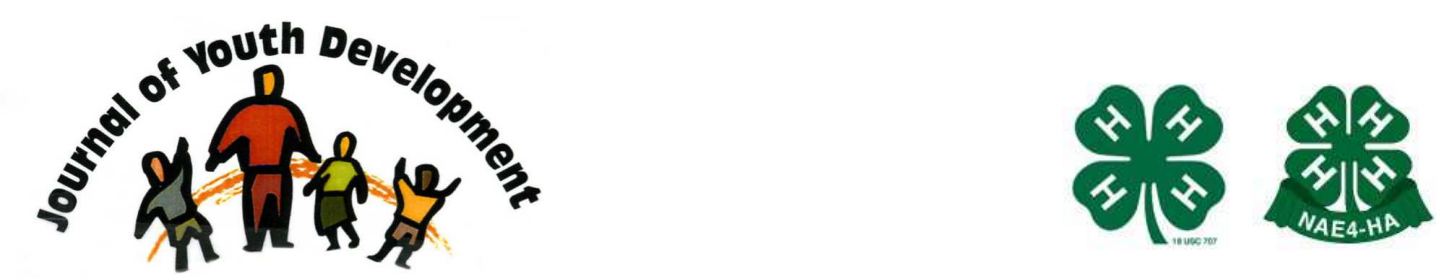

Bridging Research \& Practice

\title{
Analysis of Minority Participation in Texas' East Region 4-H and Youth Development Program in Relationship to Leadership, Marketing, and Educational Opportunities
}

\author{
Montza Williams \\ 4-H and Youth Development \\ Texas A\&M University \\ ml-williams@tamu.edu \\ Jeff W. Howard \\ 4-H and Youth Development \\ Texas A\&M University \\ j-howard@tamu.edu
}




\title{
JOURNAL OF YOUTH DEVELOPMENT \\ bridging research and practice

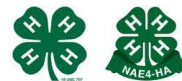

\section{Analysis of Minority Participation in Texas' East Region 4-H and Youth Development Program in Relationship to Leadership, Marketing, and Educational Opportunities}

\author{
Montza Williams and Jeff W. Howard \\ Texas A\&M University
}

\begin{abstract}
Several studies have shown that life skill development is positively related to $4-\mathrm{H}$ club participation. However, this study indicates that even though the 4-H club program is available to all youth, fewer minorities choose to participate and, thus, lose the opportunity to benefit from the positive outcomes.
\end{abstract}

Targeting specific diverse audiences has been a mandate for the 4- $\mathrm{H}$ and Youth Development Program since desegregation of the 1960s and efforts have been made to make educational programming available to everyone. Nonetheless, are current techniques being used effectively? Youth are not all alike and differences should be understood. This study gathered information that addressed some ethnic/racial issues pertaining to marketing the 4- $\mathrm{H}$ and Youth Development Program. It was determined that differences did exist for youth involved in the East Region 4-H and Youth Development Program and in order to market to the specific audiences, certain media should be used.

\section{Introduction}

Texas 4-H is one of many youth organizations which work with the goal of "meeting the needs of, and engaging young people in positive youth development experiences." These experiences are based on the idea that young people should be regarded as resources to be developed and not as problems to be managed" (Texas 4-H and Youth Development, 2002, par. 1).

Changing with the times and trying to utilize the technology available, the 4-H program has ventured in many different directions. Meeting the needs of youth through all the variables of history has been the constant goal of the $4-\mathrm{H}$ and youth development program. From 
expanding to facilitate and incorporate the desires of female youth in the beginning of the program to strengthening citizenship among young people during war times, from using television media in the 1970 s and 1980 s to encouraging computer on-line access today, the 4-H program continues to explore exciting venues to educate youth.

Through the years, programs have also been developed that target the unserved, underserved, and/or minority populations. Methodology has been established where minority representation is actively sought. Texas 4-H encourages ethnic participation and representation on committees, in leadership positions, and in 4-H club activities. The vision, mission, and value statements presented by Texas 4- $\mathrm{H}$ indicates that the program will prepare youth to meet life challenges through educational processes while developing life skills. Furthermore, the program values diversity among youth participants, families, and Extension personnel (Texas 4-H Management System, 2001).

\section{Statement of Problem}

While the 4-H program provides educational opportunities to all people, it is imperative to determine if all people benefiting from the programs that are being offered? In 2000, the United States Census Bureau reported that there were 1,475,744 potential $4-\mathrm{H}$ age youth in the Texas Cooperative Extension East Region. This number reflected the children and youth between the ages of 5 and 18 . The ethnic/racial demographics were $62.65 \%$ White, $18.92 \%$ Hispanic (includes all races), 14\% African Americans, 3.04\% Asian Pacific Islanders, and .59\% American Indian or Alaskan Native.

The East Region 4-H and Youth Development Program is conducted in 65 counties of Texas with a 2003 reported membership enrollment of 84,240 young people. The enrollment data also reported the racial-ethnicity breakdown of the membership to be 49,667 members or $58.96 \%$ describing themselves as White, not of Hispanic origin; 20,157 members or 23.93\% being Hispanic; 12,368 youth or $14.68 \%$ described themselves as African Americans, not of Hispanic origin; 1,424 members or $1.69 \%$ were of Asian or Pacific Island heritage; an 624 youth or $.74 \%$ of total enrollment described themselves as American Indian or Alaskan Native.

These data indicate that Texas East Region 4-H and Youth Development Program is attempting to serve the minority population of the region. Since the 4- $\mathrm{H}$ membership is to reflect the state's population then when looking directly at the numbers, it appears that the 4-H program is doing well in reaching all youth audiences. But attempting to provide educational opportunities to all people and deliberately designing a youth development program which has life influence are two completely different issues. Texas Cooperative Extension and the Texas Legislature expect nothing less than for the state's premier youth serving organization to benefit all youth; and it should. However, reaching all youth with some type of educational programming and providing all youth with the opportunity to develop life skills are two very different aspects of the 4-H educational program. The differences can be described within two delivery methodsthe 4-H club program and school curriculum enrichment programming. Both programs have been traditionally strong programs and are made available to all youth within the appropriate age range. However, the programs offer different educational opportunities to the young people involved.

The 4-H club experience is offered to all youth in the region but because of a variety of reasons only 14,015 East Region Texas youth chose to be involved in the 4-H club program in 2003 
(Texas Cooperative Extension, 2003). The 2003 data show the racial/ethnic membership breakdown for the East Region 4-H club program to be far different than that of the general 4-H enrollment.

Four-H club membership reflects a large majority of White members with $88.73 \%$ of the total membership followed by African American members representing 5.34\% of 4-H club membership. Hispanic members only represent $3.9 \%$ of the membership. These data show an entirely different perspective of the programming benefits. "4-H learning experiences urge youth to think and learn and apply what they have learned to their lives and surroundings" (Diem, 2001, p. 2). However, for a person to learn and make application, he must be involved in the program. So the problem becomes that the youth choosing not to participate in the 4-H program, which includes a large portion of the minority youth population, are not experiencing the life influencing opportunities that the 4-H club program offers.

\section{Purpose}

Although East Texas is a mix of ethnicities and the 4-H club experience is offered to everyone, minority youth choose not to participate in that particular opportunity on a regular or consistent basis. This study analyzed minority participation in Texas East Region 4-H and Youth Development Program in relationship to leadership that is provided through the program and the educational benefits offered through the club program as compared to the curriculum enrichment educational opportunity. The study examined youths' reasons for participating or reasons for not participating in $4-\mathrm{H}$ youth programming and determined if participation correlated to leadership. The study also examined life skill benefit perceptions provided to participants in the two delivery methods-club membership and curriculum enrichment programming.

In order to serve the purpose of this study, the following research questions were generated:

1. Is participation in Texas' East Region 4-H and Youth Development Program reflective of the diverse region's youth population?

2. Do life skill development and personal outcomes differ for participants based on the delivery method (4-H club and curriculum enrichment programs) in which they are involved?

3. Do differences exists between 4-H club members and youth not involved in the 4-H club program?

4. Are similarities of values and philosophies between member and adult leader or member and agent necessary for recruitment and retention of young people to the $4-\mathrm{H}$ and Youth Development Program?

5. Are there marketing strategies that could be used by the 4-H and Youth Development Program that could be more effective at targeting specific audiences?

\section{Theoretical Framework}

Maslow's Hierarchy of Needs (1970) introduced the idea that a person is an integrated being made up of a variety of needs. As basic needs or deficiency needs are met, the individual will move to fulfill growth needs. However, Maslow never intended that every need would have to be fulfilled completely before the individual desired to meet other needs. One of Maslow's deficiency needs is the need to belong. Every human desires to feel that they belong to a 
group in which they have close friends and in whom they can confide. As one of the deficiency needs, a sense of belonging is important for the individual. Can 4-H help to meet that basic need for all young Texans? If the 4-H program is made available and is accessible to all, why don't more youth take advantage of the opportunity afforded to them by participating in the program?

The opportunity for youth to own a sense of belonging may grow from their experiences of program ownership where their ideas and decisions play vital roles in the processes of the club. Howard (2001) determined that 4-H members do feel accepted in the 4-H program. While discussing self-esteem, Kohn (1994) observed that youth "acquire a sense of significance from doing significant things, from being active participants in their own education" (p. 282).

In partnership with the land-grant universities and the national educational system, the 4-H program has called for a collaborative effort in providing "multi-cultural programs to enhance the knowledge of and celebration for diversity in ways that break down prejudice and encourage full access, equity, and opportunity for all" (National 4-H Council, 2002, p. 6). Rodrigues (2000) stated that one great benefit of the cross-cultural experiences and cooperation "is the richness that comes from multiple perspectives" (p. 31)

With the statistics indicating that Texas is becoming more and more a multicultural state, it is important that 4-H be available and accessible to all Texas youth. Why does it matter if life skill development be available to all youth through a non-formal educational system? Boyd, Herring, and Briers (1992) compared the self-perceived life skill development of 4-H members and nonmembers and determined that $4-\mathrm{H}$ club members, as a group, rated their skill development higher than youth not involved in the 4-H program. Ladewig and Thomas (1987) indicated that skills and attitudes that were formed during the 4- $\mathrm{H}$ experience remained with the individual even into adulthood. Howard (2001) concluded that 4-H members perceived learning life skills while participating in the program. In a study conducted by Fox, Schroeder, and Lodl (2003), 4-H alumni expressed that their 4-H club experience had primary or some influence in life skill development of responsibility, self-confidence, willingness to try new things, ability to meet new people, presentation skills, and sportsmanship among others.

In 1992, Bankston interviewed minority youth in Ohio who indicated that a lack of 4-H knowledge, the image of the 4-H program, the lack of minority role models, and the fact that there was little advertising to the minority population by the 4-H program were limiting factors

to their 4-H participation. In a 2003 electronic interview with Dr. Gail Singleton Taylor, a multicultural education educator, a comment was made that alluded to the image of the 4- $\mathrm{H}$ program as being a deterrence to minority and/or urban participation.

In summary, although the $4-\mathrm{H}$ program is a proven youth development organization and the 4- $\mathrm{H}$ club is a proven method for educating youth, many youth are making the choice not to participate in the program; thus, not benefiting from the experiences being offered. All youth have the desire to belong to a group and to feel significant. As Texas' population continues to diversify, Texas 4-H must become a youth development program chosen by youth as a safe, comfortable place where they can learn skills and develop into capable, productive citizens.

\section{Population and Sample}

The population for this study included Texas Cooperative Extension East Region (65 counties) 4-H club members and Extension 4-H curriculum enrichment participants during the 2003-2004 4-H year. 
Curriculum enrichment participants may have participated in the program in 2002-2003 school year. The Texas 2003 Annual 4-H enrollment report, the ES237, indicated a membership of 84,240 total participants in the East Region 4-H Program. However, there were 14,015 children and youth involved in 4-H club programs. Extension 4-H school curriculum enrichment participation was reported at 70,225. The youth participating in the 4-H club program and the youth participating in the curriculum enrichment program became the population for this study.

The modified cluster sampling technique was used using the county as the sampling unit.

\section{Instrumentation}

This study utilized two survey instruments which targeted two specific audiences. The questionnaire was developed by the investigator following a literature review and discussion with professionals in the youth development field.

Questions in the questionnaire were separated into five areas which included demographic data, 4-H and Youth Development Programs and leadership, media exposure, future plans, and youth group involvement.

The questionnaire items were screened and reviewed by a panel of youth development experts and pilot tested with two third grade classrooms for face and content validity. Since the survey could be used with all age groups from children the age of nine to youth 19 years of age, wording was adjusted to a 4.63 reading level so that all audience members could comprehend the questions. Two third grade teachers, an elementary school counselor, and a special education teacher reviewed the instrument and made suggestions.

The instrument was pilot tested with two local third grade classrooms on January 15 and January 30, 2004. Modifications were made as a result of the recommendations and the pilot testing.

\section{Data Collection}

Each selected county was mailed the appropriate survey instrument, instruction materials, and parental and participant consent forms on March 11, 2004. The state 4-H office provided the addresses for counties and, once the packets were assembled with the appropriate materials, mailed the packets from that office. The county Extension agents were asked to survey a stated audience which was either 4-H club members or curriculum enrichment participants. The county Extension agents distributed the surveys through the 4-H volunteers or the classroom teacher which ever respectively facilitated the venue for the survey.

Distribution of the questionnaires was based on the organized 4-H club minority enrollment or participation in a school curriculum enrichment program. Distribution of questionnaires targeting the club membership was based on the reported number of minority members for the 2003 4-H year. Counties reporting less than or equal to ten members received ten questionnaires. Counties reporting minority membership to be greater than or equal to 11 or fewer than or equal to 20 received 20 questionnaires. Those counties reporting membership to be equal to or greater than 21 but less than or equal to 100 received 50 questionnaires. Counties reporting a minority membership of greater than 101 received 75 questionnaires.

Questionnaires targeting the participants in the curriculum enrichment program were distributed based on the number of participants reported for 2003. Distribution of the curriculum enrichment questionnaires was based on participation enrollment. Counties reporting curriculum enrichment participation of less than or equal to 1,000 members received 30 questionnaires. Counties reporting an enrollment of 1,001 up to and including 2,500 received 
75 questionnaires. Counties reporting a curriculum enrichment enrollment greater than or equal to 2,501 received 125 questionnaires.

By the April 30, 2004 deadline, 214 surveys were returned to the researcher. Of the total, 166 were from 4-H club members while 48 were from curriculum enrichment participants. Since only $9.23 \%$ were returned from the curriculum enrichment sample, the researcher called county Extension agents who had submitted only a few or none of the questionnaires. Following these contacts, 110 more completed instruments were returned and used for the study. A total of 354 surveys or $33.88 \%$ were returned to the researcher. Of this total $18.76 \%$ were from $4-\mathrm{H}$ club members and $15.12 \%$ were from curriculum enrichment members.

Respondents were dichotomized as either early or late by the date their questionnaires were received back to the researcher. Early respondents were those whose questionnaires were received before the original April 30, 2004 deadline. Early respondents totaled 214 (60.45\%). Late respondents were those whose questionnaires were received between May 1, 2004 and May 14, 2004 (140, 39.55\%).

\section{Data Analysis}

The data generated from the questionnaire were both descriptive and comparative. Frequency counts were completed for each question. Furthermore, the data were assembled by subject ethnicity and by age thirteen and younger or fourteen and older. A valid response required that the respondent answered the age and ethnicity questions. The data were analyzed using the Statistical Package for Social Sciences (SPSS) to determine if relationships existed between 4-H members and curriculum enrichment participants in relationship to ethnicity, leadership relationships, and perception of life skill development. 
Since only 214 questionnaires (20.48\%) were returned by the original deadline, early and late respondents were compared, using $t$ tests, on selected variables. Comparisons between early and late respondents were made on demographic information, factors determining difference, media exposure, educational goals, and organization activity level (Lindner, Murphy, \& Briers, 2001).

The age of the participants ranged from less than or equal to 9 years of age to equal to or greater than 17 years old (354). A majority of the participants were between the ages of 10 and 12 years old $(70.5 \%, 214)$. Responding club members had a greater range in age than did curriculum enrichment participants. Club members ranged in age from 9 years to 17 years of age (196) while curriculum enrichment members ranged from 9 to 15 years of age (158).

Participants were asked to respond to the questions pertaining to Hispanic descent first and then to respond to five racial categories. These five categories of White, Black or African American, American Indian or Alaskan Native, Asian, and Native Hawaiian or Pacific Islander corresponded with the categories found in the 2000 United States Census (2003). Sixteen Hispanic respondents did not mark a racial category after marking Hispanic to the ethnicity question. The idea of being Hispanic, which is now considered an ethnicity instead of a race, and also a racial category may have been confusing to some. One can be Hispanic and also be from any racial group. The sample for this study was comprised of 297 or $87.9 \%$ White, 34 or $10.1 \%$ Black or African American, 5 or $1.4 \%$ American Indian or Alaskan Native, 1 or $0.3 \%$ Asian, and 1 or $0.3 \%$ Native Hawaiian or Pacific Islander. Added to this group were the 16 Hispanic respondents not selecting a racial group once selecting the Spanish descent option. The total sample size was 354 youth-196 4-H club members and 158 curriculum enrichment participants.

Females represented a larger percentage than males with $63.6 \%$ (225) of the sample population. Males comprised $36.4 \%$ (129) of the sample. Females represented a larger percentage in both the club and curriculum enrichment groups.

The majority $(87.3 \%, 309)$ of the respondents lived in a town or city of 10,000 to 50,000 residents or its suburbs, in a town under 10,000 population, rural non-farm, or on a farm. Of these, $49 \%$ of the $4-\mathrm{H}$ members lived on a farm while $58.9 \%$ of the curriculum enrichment participant respondents lived in a town or city with 10,000 to 50,000 population or its suburbs.

\section{Conclusions}

The conclusions for this study are based on the findings from the questions that made up the various sections of the survey instrument. Each question is presented along with the results.

\section{Question One}

Is participation in Texas East Region 4-H and Youth Development Program reflective of the diverse region's youth population?

The results of this study indicate that the total 4-H program in the East Region is fairly reflective of the same area's demographics. The data show that the 4-H and Youth Development Program is educating a greater percentage of the White and Asian or Pacific Islander ethnic/racial categories than Black, Indian, or Hispanic groups in relationship to the population. 
However, for the three ethnic/racial groups that show less than the population, the shortages are not significant. The greater disparages show when comparing the delivery method known as the 4-H club program with the potential youth population. When this comparison is made, the 4-H club program falls short in three ethnic/racial categories including Black or African American, Asian or Pacific Islander, and Hispanic.

\section{Question Two}

Do life skill development and personal outcomes differ for participants based on the delivery method-4-H club or curriculum enrichment program-in which the participant is involved?

Eleven life skills or personal outcomes were listed in the questionnaires to obtain a response from 4-H club members and curriculum enrichment participants including:

1. learn more about topics of interest,

2. become involved in leadership activities,

3. be active in community through service projects,

4. accept new challenges,

5. develop personal responsibility,

6. learn to set goals,

7. help me with organizational skills,

8. make healthy life choices,

9. helped me to work with others,

10. taught me that other people are important, and

11. share my ideas with others.

Through their curriculum enrichment experience, participants are taught that others are important and learn how to share their ideas with their fellow students. The strong association with these specific statements could be related to the fact that curriculum enrichment occurs within the school setting and that these two ideas are taught throughout the educational process.

Neither group sample had a significant association with the six statements of

1. accept new challenges,

2. develop personal responsibility,

3. learn to set goals,

4. helped me with organizational skills,

5. make healthy life choices,

6. helped me to work with others.

\section{Question Three}

Do differences exist between 4-H club members and youth not involved in the 4-H club program? 
Yes, differences do exist between 4-H club members and the youth involved in curriculum enrichment programming. The four factors-race and ethnicity, music preference, extracurricular activity involvement, and educational goals-which were used in this study to determine difference indicated significant differences between those youth participating in 4-H club programming and those participating in curriculum enrichment programming.

Sample 4-H club members were predominately White $(89.9 \%)$ with $76 \%$ of the respondents living on a farm or a small town with a population under 10,000 people. For this study, curriculum enrichment participants represented youth not involved in the 4-H club program and were represented with 58.9\% Hispanics along with $11.4 \%$ Black or African American youth. Over $50 \%$ of this group lived in a town or city where the population ranged between 10,000 and 50,000 people or they lived in its suburb.

The second factor to determine difference was preferred music style. Respondents selected the four styles of country, rap/hip hop, Christian/gospel, and rock as the preferred options. Of these four selections, 4-H members chose in descending order country, rap/hip hop, Christian/gospel, and rock. Although the same four styles were selected by curriculum enrichment participants, the order was somewhat different. Curriculum enrichment participants preferred the styles in the following order-rap/hip hop, country, and an equal percentage selecting rock and Christian/gospel. The greatest difference is within the percentages of the selections. Even though both groups selected country and rap/hip hop, there is a significant difference between the music preferences between the groups.

Another variable where difference was determined was other activities in which 4-H members and curriculum enrichment members were involved. Seventeen youth organizations were named where respondents could mark their involvement. Of the 17 organizations and activities represented in the questionnaire, there were nine in which 4-H club members were more significantly involved than curriculum enrichment participants. These clubs or activities included

1. career related clubs $-46.6 \%$,

2. student government-7.6\%,

3. academic contests- $21.9 \%$,

4. school athletics-20.5\%,

5. junior livestock associations-35.8\%,

6. church youth groups-24.5\%,

7. honor clubs-13.8\%, and

8. religious clubs- $9.7 \%$.

Four-H club members also indicated that they were involved in other activities $(21.4 \%)$ at a more significant level than non $4-\mathrm{H}$ club youth.

Future career and educational goals were two other determining factors of difference between 4-H club members and non 4-H youth. Participating 4-H club members had more interest in careers related to agriculture than did other youth. Curriculum enrichment youth had more interest in becoming lawyers, law enforcement officers, and joining the military. Both groups 
seemed to understand the importance of an education with plans to obtain college and graduate degrees. A baccalaureate degree was important to $83.2 \%$ of the $4-\mathrm{H}$ club member respondents and $75.5 \%$ of the curriculum enrichment participants. Respondents wishing to obtain graduate degrees were $44.9 \%$ among curriculum enrichment participants and $44.8 \%$ among 4-H club members.

\section{Question Four}

Are similarities of values and philosophies between member and adult leader or member and agent necessary for recruitment and retention of young people to the 4- $\mathrm{H}$ and Youth Development Program?

Although some research (Gear,1992; Jones, \& Bowens, 1998; Rosado, 1994) indicates that racial/ethnic groups enjoy having people like themselves in leadership positions in organizations to which they belong, the responding sample for this study did not think it necessary that their leader be like them or have similar beliefs and ideas in order for the participants to join or remain in an activity or organization. Ladson-Billings (1994) stated that it is unclear whether the race and ethnicity of the educator affects individual learning. Rodrigues (2000) stated that it is imperative that youth development organizations allow the opportunity for their clientele to understand and interact with various cultures. He went on to say that for an organization to be regarded as multicultural, "it should reflect the presence, contributions, strengths, and aspirations of all its constituents across the spectrum of cultural, racial, and ethnic differences" (p. 24).

\section{Question Five}

Are there marketing strategies that could be used by the 4- $\mathrm{H}$ and Youth Development Program that could be more effective at targeting specific audiences?

It has been determined that youth involved in the 4-H program do have specific music preferences as compared to youth not involved in the club program. Adolescents and youth within and outside the 4-H program watch television and read magazines. Zollo (1995) reported that $85 \%$ of teens recommended that radio be used as an effective way to reach them. Seventy-five percent of teens indicated that magazines were another effective tool (Zollo, 1995). This research indicated that race/ethnicity is a factor for respondents when choosing and reading magazines as well as for how much and at what times they watch television. At least half of the respondents in the racial/ethnic categories of White, Black or African American, and Hispanic frequently visit clothing and grocery stores. At least $70 \%$ responded that they frequent department stores like Wal-Mart ${ }^{\circledR}$ or Target $^{\circledR}$.

\section{Recommendations}

The following recommendations for actions are based on the findings and conclusions of this study.

1. Since programmatic and personal outcomes differ between the two delivery methods of the 4-H club program and curriculum enrichment program, emphasis should be given to development of specific goals that are established for the variety of delivery methods that are used. The topic of interest and the delivery method would be different but the life skill development may or may not be the same for all program efforts. The $4-\mathrm{H}$ and 
Youth Development Program should develop a list of targeted life skills for all supported areas.

Specifically, the six life skill statements which neither group showed significant association are areas in which the $4-\mathrm{H}$ program should emphasize. The program states that it is building life skills in these areas but when the clientele are not responding as such, the program should review and renew specific emphases.

2. Faculty should continue to reach out to a variety of audiences. However, the method of distributing the information may need to be more targeted and specific to the audience of choice. A mass production and distribution of information will not work for all audiences. Because specific targeted audiences gather information from different sources, county Extension agents need to utilize a variety of methods in order to reach and interest those audiences. Establishing relationships with specific media outlets such as Spanish speaking radio and/or print media that may be significantly different than what has been historically used will be a key to informing and relating to a diverse public. Collaborations need to be established with local businesses such as the grocery stores, clothing markets, and department stores so that Extension faculty have the opportunity to set up displays and promotions where youth can see, hear, and learn about the 4-H and Youth Development Program opportunities.

3. Even though respondents stated that it did not matter to them whether or not their leaders were similar to them, agents should make every effort to recruit diverse volunteers who may not only attract a diverse clientele but could also provide a different perspective to the group dynamic. The proven methods for identifying community leaders should be used when targeting a new audience. DeYoung (1988) suggested relationship marketing when needing to share information at a personal level. Building a relationship of trust will secure a positive proponent of the program and could provide future benefits even if a leader enrollment form is not completed.

4. Because of the large percentages of all respondents but especially underserved audiences who said they watch movies at home, the 4- $\mathrm{H}$ and Youth Development Program should investigate the opportunity to attach public service announcement type information as a preview to movies.

\section{References}

Bankston, J. (1992). Factors related to recruitment and retention of ethnic minority youth in the Ohio 4-H program. Unpublished doctoral dissertation, The Ohio State University, Columbus.

Boyd, B., Herring, D., \& Briers, G. (1992). Developing life skills in youth [Electronic version]. Journal of Extension, 30 (4). Retrieved on February 10, 2004 from http://www.joe.org/joe1992winter/a4.html

DeYoung, B. (1988). What's relationship marketing? [Electronic version]. Journal of Extension, 26 (3). Retrieved March 16, 2004 from http://www.joe.org/joe/1988fall/a9.html 
Diem, K. (2001). The learn-by-doing approach to life skill development [Electronic version]. [Brochure]. Retrieved February 10, 2004 from The State University of New Jersey, Rutgers Cooperative Extension at http://www.rce.rutgers.edu/pubs/pdfs/fs891.pdf

Fox, J., Schroeder, D., \& Lodl, K. (2003). Life skill development through 4-H clubs: The perspective of 4-H alumni [Electronic version]. Journal of Extension, 41 (6). Retrieved on February 10, 2004 from http://www.joe.org/joe/2003december/rb2.shtml

Gear, C. (1992). An emphasis on diversity in CES [Electronic version]. Journal of Extension, 30 (3). Retrieved February 10, 2004 from http://www.joe.org/joe/1992fall/tp1.html

Howard, J. (2001). Impact assessment of the Texas 4-H and youth development program. Unpublished doctoral dissertation, Texas A\&M University, College Station.

Jones, K., \& Bowen, B. (1998). Influence of student and school factors on African American enrollment in agricultural science courses [Electronic version]. Journal of Agricultural Education, 39 (2), 39-49. Retrieved February 26, 2003 from http://pubs.aged.tamu.edu/jae/pdf/vol39/3902-39.pdf

Kohn, A. (1994). The truth about self-esteem. Phi Delta Kappan, 76, 272-283.

Ladewig, H., \& Thomas, J. (1987). Does 4-H make a difference? College Station: Texas A\&M University System, Texas Agricultural Extension Service.

Ladson-Billings, G. (1994). What we can learn from multicultural education research. Educational Leadership, 51 (8), 22-26.

Lindner, J.R., Murphy, T.H., \& Briers,G.E. (2001). Handling nonresponse in social science research [Electronic version]. Journal of Agricultural Education, 42 (4). Retrieved June 29, 2004 from http://pubs.aged.tamu.edu/jae/pdf/vol42/42-04-43.pdf

Maslow, A.B. (1970). Motivation and personality ( $2^{\text {nd }}$ ed.). New York: Harper \& Row Publishers.

Miller, L.E., \& Smith, K.L. (1983). Handling nonresponse issues [Electronic version]. Journal of Extension, 21, (5). Retrieved June 29, 2004 from http://www.joe.org/joe/1983september/83-5-a7.pdf

National 4-H Council. (2002, May). The national conversation on youth development in the $21^{\text {st }}$ century: An agenda for positive youth development. Chevy Chase, MD: National 4-H Council.

Rodrigues, L. (2000). Multicultural challenges in 4-H youth development: Bridging the divide [Electronic version]. The Center. Retrieved April 25, 2003 from http://www.fourh.umn.edu/educators/research/center/PDF/C2K-A3.pdf

Rosado, L.A. (1994). Promoting partnerships with minority parents: A revolution in today's restructuring efforts [Electronic version]. The Journal of Educational Issues of Language Minority Students, 241-254. Retrieved on August 14, 2003 from http://www.ncela.gwu.edu/miscpubs/jeilms/vol14/rosado.htm 
Texas 4-H Management System. (2001). County Management Guide. College Station, TX: Texas Cooperative Extension.

Texas 4-H and Youth Development. (2002). Investing in positive youth development. [Brochure]. College Station, TX: Texas Cooperative Extension.

Texas Cooperative Extension. (2003). ES-237 statistical report. College Station, TX: Texas Cooperative Extension.

U.S. Census Bureau. (2003). Texas Quick Facts. Retrieved December 4, 2003 from http://quickfacts.census.gov/afd/states/48000.html

Zollo, P. (1995). Wise up to teens: Insights into marketing and advertising to teenagers. Ithaca, NY: New Strategist Publications, Inc.

(C) Copyright of Journal of Youth Development Bridging Research and Practice. Content may not be copied or emailed to multiple sites or posted to a listserv without copyright holder's express written permission. Contact Editor at: patricia.dawson@oregonstate.edu for details. However, users may print, download or email articles for individual use.

ISSN 2325-4009 (Print); ISSN 2325-4017 (Online) 